company owns lamps and posts. In 1904 there were 9,337 Welsbach gas lamps in use, paid for at the rate of $\$ 30$ per lamp per annum. In accordance with the contract of the city with the Rising Sun Company, the city derives benefit from any reduction in the cost of gas in Boston; so that the city is now, i. e., since July I, 1905, paying $\$ 29.40$ per lamp per annum, and will pay $\$ 28.80$ for the same after January I, 1906. In I904, I,49I open-flame and 538 Welsbach naphtha lamps were in use for public street-lighting, at $\$ 22.8 \mathrm{I}$ and $\$ 29.20$ per lamp per annum respectively, and the same rates for naphtha lamps obtain in 1905.

In 1904 there were 3,699 electric arc lights in use for public lighting against 3,731 now in use (1905). Then, as now, the price per lamp varied from 33 to 35 cents per night, or $\$ 120.45$ to $\$ 127.75$ per annum. Of incandescent lamps there were thirty-eight in 1904 , at prices varying from $\$ 2.50$ to $\$ 3.00$ for some, and one cent per lamp per hour, less 25 per cent. for others.

\title{
CLEVELAND
}

By F. E. Stevens, Secretary Municipal Association of Cleveland.

\section{The Gas Service.}

Two companies furnish the gas supply of the city-the Cleveland Gas Light and Coke Company to that portion of the city east of the Cuyahoga River, and the People's Gas Light Company to the portion west of the river.

The original grant was made to the first of these two companies in 1849 . Permission was given to lay pipes under supervision and certain restrictions. The company was required to furnish gas to the city for public lighting at a price not to exceed that paid in Buffalo or Cincinnati, and to citizens at a price not to exceed $\$ 3.00$ per thousand cubic feet. The city was to furnish and own the lamps. The city might also extend pipes and connect with mains when the companies refused to do so. For this service the company was to reimburse the city before they could use these pipes to deliver gas to private consumers.

The charter of the second company was granted in 1867 . It contained provisions similar to those already stated, except that it was required to furnish gas for public lighting at a price not to exceed $\$ 2.25$. After twenty years the city was to have the right to purchase the plant at a fair price to be fixed by five disinterested persons.

In the franchises the right is reserved by the city council to regulate the price of gas for ten-year periods. The last ordinance for this purpose was passed in July, Igoo. By the terms of this ordinance the maximum and minimum price to be charged for public and private consumption is fixed at 75 cents per thousand cubic feet. The companies are required to install and maintain meters without charge to the consumer, but a deposit of $\$ 5.00$ is required for each meter installed, this deposit to be returned upon discon- 
tinuance of the use of gas or removal of the meter. No free lights for public service are provided. The companies are required to pay into the city treasury $6 \mathrm{t} / 2$ per cent. of their gross receipts. For the year of 1904 the receipts from this source amounted to $\$ 86,623.98$. This amount is additional to the receipts from taxation of the property of the company. The companies are subject to a general property tax the same as any other corporation or individual. Hitherto it has been very much under-assessed. The assessment, however, more than doubled in the last three years, while previously very trifling increases had been made from year to year.

Until recently the gas companies supplied and maintained the equipment of street lighting. A different policy now obtains. The city owns and maintains all of the equipment and lights the lamps. The gas for the lamps is, however, purchased of the companies. By means of frequent tests the value of the gas consumed by each lamp per year is for the present fixed at $\$ 5.43$. Nine thousand three hundred and seventy-seven lamps of seventeen-candle power are thus provided. The city also maintains $\mathrm{I}, 500$ gasoline lamps. These latter are being gradually displaced by the gas lamps.

As a means of determining the amount due the city from the receipts of the gas companies the companies are required to submit, semi-annually, sworn statements showing the quantity of gas manufactured and the receipts from its sale. The city is empowered to examine the books and accounts of the companies and this is done by the city auditor. The city has no right under the franchises of the companies to purchase their plants.

Some two years ago a franchise was granted to the East Ohio Gas Company to supply natural gas for fuel purposes. The old gas companies vigorously contested this grant, as a large portion of their business consisted of supplying gas for fuel. The natural gas company supplies gas for $3 \mathrm{I}$ cents per thousand feet. That the entry of this company into the field has had a very considerable effect upon the business of the artificial gas companies cannot be doubted.

The Cleveland Gas Light and Coke Company, capitalized at $\$ 4,000,000$ has paid dividends of 8 per cent. until recently, when the dividend was reduced to 6 per cent. The People's Gas Light and Coke Company, capitalized at $\$ 1,000,000$ maintains its regular 7 per cent. dividend payment, the natural gas company not having as yet encroached greatly upon west side territory.

\section{The Electric Light Service.}

The electric light service is supplied entirely by one company-the Cleveland Electric Illuminating Company. It has a perpetual franchise and the city has no right to purchase the plant. There are no restrictions upon charges and no contract right in the city to regulate service or charges. It supplies the city with 1,238 arc lights, 2,000-candle power, at a cost per annum of $\$ 73.56$ each. This charge is a considerable reduction from the figures of former years.

The city uses no incandescent lights on its streets. The charges for private lighting are as follows: For an average use of forty hours per month of the 
lamps connected at $12^{1} / 2$ cents per unit; and for any current in excess of said average use of forty hours per month of the lamps connected at 5 cents per unit. (A unit is 1,000 Watt hours.)

In consideration of 5 cent rate, consumer agrees that his bill shall not be less in any month than $\$$ - , being a basis of $\$ 2.50$ for each arc lamp and $\$ 1.00$ for each ten sixteen-candle power lamp or proportion thereof installed. For power, I2 $1 / 2$ cents for each 1,000 Watt hours, less 50 per cent.

The above are the rates charged and published, but wherever there is competition from private power companies in power blocks, etc., secret rates are made. Gas lamps are located at an average distance from each other of I50 feet and arc lights are placed from 300 to 400 feet apart. All streets are not, however, equally well lighted, the above apportionment of lights indicating the average provision for the streets.

\section{BUFFALO}

\section{The Gas Service.}

The gas lighting service of Buffalo is rendered by a private enterprise under the name of the Buffalo Gas Company. This company, which controls the entire lighting of the city (by gas) was organized in October, 1899, and is a consolidation of the Buffalo City Company and the Buffalo Gas Light Company. It also owns the entire capital stock of the Buffalo United Gas Light Company and about go per cent. of the People's Company. The company operates under a perpettial franchise. The requirements as to service are fixed by periodical contracts. The contract now in force covers a five-year period from March I, 1902, to March I, 1907. The company is bound to light, extinguish, clean and keep in repair the public street gas lamps, for which service it receives 17 cents per month per lamp. It is required to furnish gas of not less than eighteen-candle power to both the city and the private consumer. The company has a capital stock of $\$ 2,000,000,6$ per cent. non-cumulative preferred, and $\$ 7,000,000$ common issued in exchange for the shares of the old companies. There is a bonded indebtedness of $\$ 5,900,000$ first mortgage 5 per cent. gold, issued in 1897, due in 1947, secured by all the property of the company and by a pledge of the bonds and stocks of the People's Gas Light and Coke Company owned by the Buffalo Gas Company. A franchise tax has been levied annually since I900, but no such tax has been paid for any year. The tax for the year $1904-05$ is $\$ 39,187.49$ plus $\$ 920.95$ levied in name against a constituent company.

By the contract already mentioned the prices for lighting are to be as follows :

Public Lighting.-To light not less than 5.500 lamps:

March I, 1902, to March I, 1903, $\$ 0.79$ per I,000 cubic feet.

March 1, 1903, to March I, 1904, .78 per 1,000 cubic feet.

March I, 1904, to March I, 1905, .77 per I,000 cubic feet. 